\title{
Consumer Perceptions towards Sustainable Supply Chain Practices in the Hospitality Industry
}

\author{
Patrizia Daniela Modica
}

Levent Altinay

Anna Farmaki

Dogan Gursoy

Mariangela Zenga

\begin{abstract}
This study investigates the impacts of economic, social and environmental sustainability practices of companies in the hospitality supply chain on consumers' satisfaction, loyalty and willingness to pay higher prices. Utilising data collected from 288 tourists visiting south Sardinia, the study indicates that while economic sustainability practices have positive impacts on consumers' satisfaction, loyalty and willingness to pay a premium, sustainability practices related to environmental and social dimensions have a direct positive impact on satisfaction and an indirect positive impact on consumer loyalty and willingness to pay a premium. Additionally, findings reveal that satisfaction is likely to mediate the impact of environmental and social sustainability practices on the loyalty of consumers. The theoretical and managerial implications of the study are provided.
\end{abstract}

Keywords: sustainability; supply chain practices; hospitality; consumer perceptions; Sardinia

\section{Introduction}

In recent years, the concept of sustainability has gained currency among practitioners in the hospitality industry. The reason for the increased popularity of sustainability in hospitality is two-fold. First, sustainability in hospitality has become a significant determinant influencing consumer perceptions and decision-making aspects such as the loyalty of consumers and the willingness of consumers to pay exceptional prices (Teng et al, 2012). Second, the significance of sustainability within the tourism and hospitality industries has been increasingly emphasised by governments and community organisations that place pressures on companies to align their practices to sustainability principles (Xu and Gursoy, 2015a). The hospitality industry, in particular, has been acknowledged as a key supplier of the tourism product with significant contribution to destinations' economies which, nonetheless, imposes pressures on the environment and the host community (de Grosbois, 2012). The increased popularity of sustainability issues in hospitality is reflected by a proliferation of studies focusing on the antecedents, impacts, actions and evaluation mechanisms of sustainability practices (e.g. Berezan et al, 2013; Chen, 2015; Kang et al, 2012). These studies are insightful and informative of the influence of sustainability on consumer perceptions, attitudes and behaviour.

Nonetheless, a foray into extant literature identifies a one-dimensional focus of past studies. For instance, most studies have centered investigation on of sustainability, focusing either on the environmental aspect such as green practices (e.g. Namkung and Jang, 2017) or on the social aspect including corporate social responsibility (e.g. Martinez and del Bosque, 2013). Additionally, most previous studies concentrated on a single sector of the hospitality industry such as hotels or restaurants, overlooking the importance of the involvement of all 
the stakeholders of the hospitality supply chain in sustainability (Lo et al, 2017; Shin et al, 2017). As Xu and Gursoy (2015a: 229) stated "true sustainability can be achieved only if all members of a supply chain participate in sustainability practices". In a conceptual framework developed by $\mathrm{Xu}$ and Gursoy (2015a), the supply chain is acknowledged as possessing specific characteristics that emanate from both manufacturing and service supply chains. According to the authors, the effective management of the supply chain requires the adherence to environmental, social and economic aspects as indicated by the triple bottom line approach (Hall et al, 2012), which became known as representing the three objectives of sustainable development. Insofar, there has been limited academic attention devoted to the influence of all three sustainability dimensions in relation to the management of hospitality supply chain practices.

While research has been performed on the impact of sustainable hospitality supply chain practices on consumer behavioral aspects, past studies evaluating customer perceptions and attitudes towards sustainable practices in hospitality have focused on specific sustainability dimensions (i.e. environmental) or on consumers from specific geographical region (Chin et al, 2018; Xu and Gursoy, 2015b). For example, Xu and Gursoy (2015b) examined impacts of environmental, social and economic dimensions of sustainable hospitality supply chain management practices on American travellers' attitudes and behaviours including satisfaction, loyalty and willingness to pay a premium for sustainable hospitality goods and services. Their results indicated that both environmental and economic dimensions' practices have positive impacts on American consumers' satisfaction, loyalty and willingness to pay a premium for sustainable hospitality goods and services, the social dimension practices were found to have positive impact on satisfaction and a negative impacts on willingness to pay a premium. They also reported satisfaction to fully mediate the relationship between social dimension practices and loyalty. However, Xu and Gursoy (2015b) indicated that their findings may not be applicable to consumers outside the United States because American consumers tend to exhibit significantly different attitudes and behaviours towards green products compared consumers located in other geographical regions of the world. For example, studies suggest that European consumers are 50\% more likely than American consumers to purchase environmentally friendly sustainable products (Thompson 2007). Thus, it is critical to examine perceptions and attitudes of consumers located in different geographical regions towards sustainable practices in hospitality. Therefore, this study aims to advance our knowledge on the impact of sustainability practices on consumers' attitudes and behaviours by focusing on European travellers' hotel selection process. Specifically, this study examines the influence of sustainability practices of companies in the hospitality supply chain related to environmental, social and economic dimensions of sustainability on the behavioural aspects of customer satisfaction, loyalty and willingness to pay a premium price, which emerge as most predominant in extant literature.

The rest of the paper is organised as follows. First, a review of the literature is provided in order to establish the theoretical background of the study and contribute to the development of hypotheses. The importance of sustainability in the hospitality supply chain is explained before an overview of past studies evaluating the impacts of sustainable supply chain management practices on consumer perceptions is provided. Then, the methodology adopted in this study is described. Following, the results of the data analysis are presented before the implications, limitations and future research directions are drawn together as conclusions. 


\section{Literature Review}

\section{Sustainability in hospitality supply chain management}

Extant literature on supply chain management identifies two predominant forms of supply chains: manufacturing and service supply chains. The first refers to a process whereby units are transformed from raw materials into products and sold to end-consumers whereas the latter is defined as the inbound and outbound service experiences offered to consumers by firms (Miles and Snow, 2007). The hospitality supply chain possesses elements of both manufacturing and service supply chains. Specifically, it has been defined by Xu and Gursoy (2015a: 232) "as a network of hospitality organisations engaged in different activities including the supply of various components of hospitality products and/or services such as raw food materials, equipment and furniture from various suppliers; distribution and marketing of the final hospitality products and/or services to the consumers for a specific hospitality business such as a hotel or a restaurant". Therefore, the management of the supply chain in hospitality extends beyond procurement and logistics and differs from a traditional supply chain along six features. First, hospitality products are perishable with the variable cost of the hospitality product often being lower than fixed costs (Guo et al, 2013); hence, revenue management is important for hospitality suppliers. Second, the generation of consumer demand is crucial in hospitality, particularly in relation to positive word-of-mouth (Cantallops and Salvi, 2014). Third, there are various suppliers providing the hospitality product with the hospitality supply chain being characterised as a close-loop one (Xu and Gursoy, 2015a). Fourth, demand for hospitality products is uncertain due to intense competition among hospitality companies and the industry's susceptibility to external factors such as the weather (Zhang et al, 2009). Fifth, the simultaneous production and consumption of the hospitality product problematises logistics. Last, collaboration among hospitality business is crucial as multiple hospitality products provided by various companies are offered to consumers as a package.

In recent years, arguments concerning the importance of aligning the hospitality supply chain to sustainability principles have intensified. Driven by the realisation that all members of the supply chain need to participate in sustainability efforts, researchers in hospitality advocate the implementation of sustainability practices from the upstream of the supply chain, highlighting the importance of supplier selection and cooperation (e.g. Xu and Gursoy, 2015a). Studies on traditional supply chains indicate the consideration of environmental, social and economic aspects as imperative in effective supply chain management (Hall et al, 2012). Likewise, $\mathrm{Xu}$ and Gursoy (2015a) identified the triple bottom line approach to sustainability as critical in hospitality for the successful implementation of sustainable development objectives, namely economic, social and environmental sustainability. In other words, hospitality suppliers need to ensure that the negative impacts on the environment resulting from their actions are minimised, that their operations enhance the social welfare of related stakeholder such as employees, consumers and other suppliers and that profit is generated long-term. A range of benefits have been identified as emanating from the sustainable practices of hospitality supply chain members. For instance, company image may be enhanced (Han et al, 2011) whilst the profitability of all supply chain members may be improved (Molina-Azorin et al, 2009). In evaluating the positive impacts of sustainable supply chain, an important array of work has emerged discussing the influence of sustainability practices on consumer behavioural aspects. Specifically, satisfaction, loyalty and willingness to pay an exceptional price emerge as the most predominant variables examined in relation to consumer perceptions and attitudes towards sustainability practices. Previous studies confirm the positive influence of sustainable hospitality supply chain practices on consumer perceptions and behaviours, as consumers are becoming increasingly 
conscious over the environmental-friendly and responsible aspects of products and services (Cronin et al, 2011).

\section{Supply management and consumer perceptions}

The majority of studies looking into the impact of sustainable supply chain practices on consumer perceptions focused on the relationship between the three dimensions of sustainability and consumer satisfaction. Defined as "a person's feeling of pleasure or disappointment which resulted from comparing a product's perceived performance or outcome against his/ her expectations" (Kotler and Keller, 2006:144), satisfaction has been widely examined in hospitality studies (Cicerali et al, 2017). Generally speaking, consumer satisfaction is an indication of company success in providing products and services efficiently and in creating value for consumers. Management literature indicates that high consumer satisfaction translates into higher profits, larger market share, repeat purchase, positive wordof-mouth and enhanced company reputation (e.g. McDougall and Levesque, 2000). In relation to the hospitality product, which exhibits specific characteristics in comparison to traditional products, consumer satisfaction has been acknowledged as being highly important for company profitability. Recently, as the importance of sustainability for hospitality consumers increased, academic attention has shifted towards the relationship between sustainability practices and consumer satisfaction as evidenced by a burgeoning number of studies examining the contributory role of sustainability actions on consumer satisfaction.

Specifically, several studies have examined the impacts of the three dimensions of sustainability on consumer satisfaction. However, most of those studies have focused on the examination of the relationship between a single dimension of sustainability and satisfaction. Representing an energy-intensive and waste generating industry, the hospitality sector has been under pressure from environmental groups and non-profit organisations to minimise its negative environmental impacts. Likewise, the increased consciousness of consumers led many hospitality businesses to adopt environmental-friendly practices in an attempt to reduce their environmental footprint. Thus, in relation to the environmental dimension, it has been found that consumer satisfaction is positively impacted by environmental-friendly actions of hospitality companies (Berezan et al, 2013; Lu and Stepchenkova, 2012; Slevitch et al, 2013). Specifically, Gao and Mattila (2014) found that consumer satisfaction increased when companies were engaged with environmental-friendly practices. Similarly, Yu et al (2017) argued that hotels' green practices contribute to consumer satisfaction whereas Graci and Kuehnel (2011) established a positive relationship between green practices of hotels and reduced operating costs. Indeed, consumer satisfaction was found to mediate between environmental practices and companies' financial performance (Kassinis and Soteriou, 2003). Interestingly, in evaluating the impact of economic sustainability on consumer satisfaction, studies found that good financial performance acts as an antecedent of high satisfaction (Jung and Yoon, 2013; Lo et al, 2015). The financial performance of companies is an indication of their capability to offer high quality services, which is a determinant of consumer satisfaction (Sanchez-Fernandez and Iniesta-Bonillo, 2009). Lastly, the social dimension of sustainability has been examined in relation to consumer satisfaction with studies concurring the positive relationship between the two variables. For example, socially responsible companies have been found to offer better working conditions (Brown, 2007), thereby increasing employee satisfaction (Chi and Gursoy, 2009) and consequently consumer satisfaction as employees are likely to perform more efficiently at work (de Leaniz and Rodriguez, 2015). The impact of employee satisfaction on performance is particularly significant in the hospitality industry in which there is a close interaction between employees and consumers (Kassinis and Soteriou, 2003). Likewise, companies' socially responsible actions may contribute to company reputation and brand image (Lee and Heo, 2009) through the selection of environmental- 
friendly suppliers (Guide et al, 2003) and the cooperation with local suppliers (Holmes and Yan, 2012). Given these arguments, we develop the following hypothesis:

H1: There is a positive relationship between (a) environmental, (b) social and

(c) economic dimensions of the supply chain and consumer satisfaction.

Studies examining the impact of the three dimensions of sustainability on consumer loyalty can also be found. Consumer loyalty has been defined as the strength of the relationship between one's relative attitude and repeat purchase (Dick and Basu, 1994 Rather, 2018). Representing the attachment consumers place on products, brands and/or companies, consumer loyalty is an important construct within hospitality as it can indicate future behavioural intentions, trust and consumer identification with the company (Martinez and del Bisque, 2013; Sipe and Testa, 2018). Unsurprisingly, many hospitality companies offer reward schemes and loyalty programs in an attempt to enhance consumer loyalty and increase consumer satisfaction (Liu and Mattila, 2016). Within hospitality, the environmental dimension of sustainability has been found to contribute to the enhancement of consumer loyalty (Chen, 2015; Lee et al, 2010). As an increasing number of consumers demand green actions from hospitality companies, environmental-friendly activities can improve company reputation (Jang et al, 2015) and ultimately influence the loyalty of the consumers positively. Likewise, the social actions of hospitality companies may increase consumer loyalty. For instance, employee welfare schemes can enhance the attractiveness of a company and contribute to brand loyalty (Chi and Gursoy, 2009). Similarly, economic sustainability plays an important role in enhancing consumer loyalty. Shi et al (2014) argued that good financial performance improves the quality of products and hence contributes to consumer loyalty. Equally, good financial performance of hospitality companies strengthens company reputation and may help generate consumer loyalty (Pena et al, 2013) whereas as Jung and Yoon (2013) argued the financial performance of hospitality companies may enhance consumer loyalty indirectly by contributing to consumer and employee satisfaction. Therefore, we propose that:

$\mathbf{H}_{2}$ : There is a positive relationship between (a) environmental, (b) social and (c) economic dimensions of the sustainable supply chain and consumer loyalty.

Lastly, several studies examining the impact of sustainability practices on consumers' willingness to pay higher prices have been conducted. Generally, the ecological concerns of consumers in hospitality have been argued to increase willingness to pay for environmentalfriendly company initiatives (Chen and Tung, 2014; Lee et al, 2010; Kang et al, 2012), with Han et al (2011) suggesting that consumers engage with companies that have environmental friendly policies. Kang et al (2012) concluded that consumers of luxury hotels and midpriced hotels exhibit greater willingness to pay higher prices for environmental-friendly practices than consumers of economy hotels whereas in the context of restaurants, Namkung and Jang (2017) confirmed consumer willingness to pay premium prices for green practices. In respect to social sustainability, it was found that consumers are prepared to pay premium prices for well-trained employees and for locally produced goods (Bechwati, 2011; Onozaka and McFadden, 2011). Furthermore, the socially responsible actions of companies can enhance employee productivity and satisfaction (Lee et al, 2013) as well as support local communities through the cooperation with local suppliers, thereby increase consumer 
willingness to pay a premium. Economic sustainability should also not be ignored within the scope of consumer eagerness to pay an exceptional price. Previous research indicates that consumers are more eager to pay higher prices for the services of companies with successful performance (Campbell et al, 2014; Fornell et al, 2010). Higher willingness to pay premium prices for the products of companies with good financial performance results from higher satisfaction and higher perceptions of product quality, which are associated with the economic profitability of businesses. Thus, informed by the literature we propose the hypothesis:

H3: There is a positive relationship between (a) environmental, (b) social and

(c) economic dimensions of the supply chain and consumer willingness to pay higher prices.

Interestingly, the variables of consumer satisfaction, loyalty and willingness to pay have been found to be interrelated. For instance, Nunkoo et al (2013b) established a positive relationship between consumer satisfaction and loyalty whereas Gursoy et al (2014) argued that consumer satisfaction is an antecedent of consumer loyalty. Kim et al (2013) confirmed the positive link between the two constructs while Loureiro and Kastenholz (2011) identify perceived quality's mediating effect between consumer satisfaction and loyalty. Likewise, loyal consumers were found to be more willing to pay higher prices (Gursoy et al, 2014; Jensen and Drozdenko, 2008). Taking into account these findings, this study proposes that:

H4: There is a positive relationship between consumer satisfaction and consumer loyalty.

Hs: There is a positive relationship between consumer loyalty and consumers' willingness to pay higher prices.

\section{Methodology}

\section{Questionnaire}

The hypotheses presented in the previous section were tested utilising data collected through a self-administered questionnaire, developed by $\mathrm{Xu}$ and Gursoy's (2015a). Five sections were included in the questionnaire. In the first three sections, several items measuring the consumers' perceptions of the sustainability practices of hospitality supply chain members, hereby referred to as Sustainable Hospitality Supply Chain Management (SHSCM). Consistent with Xu and Gursoy's (2015a) definition, the hospitality supply chain (HSC) in the survey was defined "as a network of hospitality organisations engaged in different activities including the supply of various components of hospitality products and/or services such as raw food materials, equipment and furniture from various suppliers; distribution and marketing of the final hospitality products and/or services to the customers for a specific hospitality business such as a hotel or a restaurant". In particular, the first section focused on the environmental sustainability dimension. This section included 33 items that measured attention to product design, service process design, reuse and recycling, management of products during service delivery, waste and pollution management and expansion of products' life cycle among other factors. The second section contained 36 items measuring the social sustainability dimension related to employees, consumers, communities, suppliers and the government. The third section with 19 items analysed economic sustainability practices (e.g. cost control, income growth, and expansion of market share). The fourth 
section contained several items measuring consumers' behaviours and intentions such as satisfaction, loyalty and willingness to pay a premium price. Items in the first four sections of the questionnaire were measured on a 5-point Likert scale, ranging from 1 (completely disagree) to 5 (completely agree). Questions aimed to measure respondents' sociodemographic were included in the fifth section.

\section{Sample and data collection}

The sample included tourists visiting south Sardinia between May 2017 to September 2017. The respondents were selected in accordance to quota random sampling based on their nationality. A total of 327 questionnaires were completed by tourists. After eliminating responses with missing data, 288 questionnaires were retained for data analysis. Table 1 shows the socio-demographic profile of respondents. Overall, 51.1\% of the sample were female whereas the majority of respondents $(80.7 \%)$ were under 54 years old. Approximately $36.5 \%$ of the respondents were Italian, $18.8 \%$ were British, $19.4 \%$ were French and $19.8 \%$ were German. Almost $40 \%$ of the respondents were married while those being single represented $37.2 \%$ of the sample. Around $44 \%$ of the respondents worked in managerial, professional and similar positions whereas the median annual income was about 49,000 euros.

\section{$<$ Insert Table 1 About Here $>$}

\section{Data analysis}

To test the model and hypothesised relationships, structural equation modeling was conducted. In a first step, a confirmatory factor analysis (CFA) was conducted to test the construct validity, reliability and unidimensionality properties of the measurement model. Afterwards, interrelationships among the variables were estimated with the structural equation modeling. The lavaan package under software $\mathrm{R} 3.4 .0$ was utilised for all estimations (Rosseel, 2012). The proposed model and the hypotheses are presented in Figure 1 .

$$
<\text { Insert Figure } 1 \text { About Here }>
$$

\section{Results}

\section{Measurement model}

A two-step approach was utilised to estimate the measurement and structural models. First, the measurement model was estimated using the Maximum Likelihood Estimation method. Model fit was evaluated using the Goodness of Fit Index (GFI), Root Mean Square Error of Approximations (RMSEA), and the $\chi^{2}$ and relative/normed chi-square $\left(\chi^{2} / \mathrm{df}\right)$ statistics (Wheaton et al, 1977). Given that the fit indices of CFA are $\chi^{2}=1370.022,(d f=513$; $\mathrm{p}<0.0001), \frac{\chi^{2}}{d f}=2.67, \mathrm{GFI}=0.942$ and $\mathrm{RMSEA}=0.076$, we concluded that the data fit the measurement model fairly well.

Table 2 reports the properties of the measurement model 1 . As reported in Table 2, all AVE values exceeded the ideal cutting off value of 0.50 . Thus, the convergent validity of the constructs was established.

$$
<\text { Insert Table } 2 \text { About Here }>
$$

\footnotetext{
1 For the environmental, social and economic dimensions, we report only the first-order factors (not the original items). The results for each item are available on request.
} 
Next, squared correlations among the constructs were estimated (Table 3) and then compared to the AVE scores. Given that, all correlations between the constructs were less than 0.85 (Lee et al, 2013), the model discriminant validity was established. Furthermore, composite reliability scores of the constructs examined in this study varied from 0.752 to 0.978 , exceeding the established cut-off value of 0.70 (Hair et al, 2011) indicated that the items utilised to measure each construct had acceptable reliability.

\section{$<$ Insert Table 3 About Here $>$}

\section{Testing the proposed model and hypotheses}

After confirming that the measurement model was acceptable, the second step of the analysis examined the interrelationships among the constructs utilising a structural modeling approach. The indices of goodness-of-fit of the estimated structural model $\left(\chi^{2}=\right.$ 1435.394, $d f=513 ; \mathrm{p}<0.0001, \frac{\chi^{2}}{d f}=2.798, \mathrm{GFI}=0.902$ and $\left.\mathrm{RMSEA}=0.079\right)$ indicated that the proposed structural model had a reasonably good fit to the data. Figure 2 reports the properties of the structural model and the standardised path coefficients for the estimated relationships. Table 4 presents a summary of the hypotheses testing results.

\section{$<$ Insert Table 4 About Here $>$}

As presented in Table 4, the standardised paths coefficients between the environmental, social and economic sustainability dimensions of the hospitality supply chain and consumer satisfaction were significant and positive (Hpla: $\square_{\mathrm{aq}}=0.292$, p-value $<0.0001 ; \mathrm{Hp} 1 \mathrm{~b}: \square_{1 \mathrm{~B}}=$ 0.335 , p-value $<0.0001 ; \mathrm{Hp} 1 \mathrm{c}: \square_{1 \mathrm{c}}=0.133$, p-value $\left.=0.044\right)$. These findings suggest that sustainability practices of the hospitality supply chain towards environment, society and financial returns have a positive significant impact on consumer satisfaction. Hence, these results provided support for the hypotheses $1 \mathrm{a}, 1 \mathrm{~b}$, and $1 \mathrm{c}$.

As presented in Table 4, findings indicated that only the path between the economic dimension and loyalty was significant and positive $\left(\mathrm{Hp} 2 \mathrm{c}: \square_{2 \mathrm{c}}=0.120\right.$, p-value $\left.=0.019\right)$. The relationship between the environmental dimension and loyalty $\left(\mathrm{Hp} 2 \mathrm{a}: \square_{2 \mathrm{~A}}=0.025\right.$, pvalue $=0.670)$ and the relationship between social dimension and loyalty $\left(\mathrm{Hp} 2 \mathrm{~b}: \square_{2 \mathrm{~B}}=-0.090\right.$, p-value $=0.173$ ) were not found to be significant. Therefore, only hypotheses $2 \mathrm{c}$ was supported, while hypothesis $2 \mathrm{a}$ and $2 \mathrm{~b}$ were rejected. Similar to the result of Hypothesis 2, the impact of economic dimension on willingness to pay a premium was positively significant (Hp3c: $\square$ zc $=0.167$, p-value $=0.022$ ), while the standardised path coefficients between environmental and social dimension and willingness to pay a premium were not significant (Hp3a: $\square_{3 \mathrm{~A}}=0.089$, p-value $=0.267$; Hp3b: $\square_{3 \mathrm{~B}}=0.015$, p-value: 0.866 ). Therefore, hypotheses $3 \mathrm{c}$ was supported, while hypothesis $3 \mathrm{a}$ and $3 \mathrm{~b}$ were rejected. Findings further indicated a direct positive relationship between satisfaction and loyalty (Hp4: $\square_{4}=0.862$, pvalue $<0.0001$ ) and between loyalty and willingness to pay higher prices (Hp5: $\square_{5}=0.479$, p-value $<0.0001$ ), which provided support for hypotheses 4 and 5 .

Overall, the model suggests that only the economic dimension of the SHSCM has a direct positive impact on satisfaction, loyalty and willingness to pay higher prices while social and environmental dimensions have a direct positive impact only on consumer satisfaction. Moreover, the results confirm that consumer satisfaction has a positive impact on loyalty that in turn influences consumers' willingness to pay higher prices directly. 


\section{Discussion}

This study investigates the impacts of sustainability practices of companies in the hospitality supply chain on consumers' satisfaction, loyalty towards and willingness to pay higher prices. By investigating the impacts of all three dimensions of sustainability practices of the hospitality supply chain on consumers' attitudes and behaviours, this study makes important theoretical contributions to the field of hospitality. Since most pertinent studies focused on sustainability practices of individual companies on one of the three dimensions of sustainability, findings reported in this study offer important insights that advance existing knowledge on sustainable supply chain management in hospitality. Specifically, findings suggest that as the nature of competition shifts from the individual company level to the supply chain level, sustainability initiatives that are woven into the fabric of the entire hospitality supply chain can produce relatively more positive outcomes (Ashby et al, 2012, $\mathrm{Xu}$ and Gursoy 2015a).

Overall, this study suggests that all three dimensions of sustainability practices examined in this study directly and/or indirectly impact consumers' attitudes and behaviours, therefore concurring with past studies (Berezan et al, 2013; Lee and Heo, 2009, Xu and Gursoy, 2015b). While sustainability practices that focus on environmental conservation and protection have received the most attention in the literature, the current study indicates that social sustainability practices have the highest impact on consumer satisfaction $(\beta=0.34, p<$ $0.05)$, followed by environmental dimension $(\beta=0.29, \mathrm{p}<0.05)$ and economic dimension $(\beta$ $=0.14, \mathrm{p}<0.05)$.

Findings also suggest that among all three dimensions of sustainability, only economic sustainability practices tend to have a direct impact on consumer loyalty. The impacts of social and environmental sustainability practices on loyalty were found to be mediated by satisfaction. While the reported significant impact of satisfaction on loyalty is similar with the results of earlier studies (Chaudhuri and Holbrook, 2001; Wu and Cheng, 2018), the current study suggests that social and environmental dimensions indirectly impact loyalty through consumer satisfaction. This finding contradicts with previous study findings that reported a direct positive relationship between sustainability practices and consumer loyalty (e.g. Xu and Gursoy, 2015b). This contradictory finding might be due to the fact that European travellers' attitudes and behaviours toward sustainability practices performed by the member of hospitality supply chain were examined in this study, while the study conducted by $\mathrm{Xu}$ and Gursoy (2015b) was focused on American travellers' attitudes and behaviours. Nonetheless, this study corresponds to previous research reporting an indirect relationship between sustainability practices and consumer loyalty (e.g. Martinez and Bosque, 2013). Some of the earlier studies have suggested that the indirect impact of sustainability practices on loyalty might be mediated by other constructs such as service quality (Mandhachitara and Poolthong, 2011), trust in company (Martinez and Bosque, 2013) and satisfaction. This study also supports this argument.

Moreover, findings reveal that among all three dimensions of sustainability, economic sustainability practices directly influence consumers' willingness to pay higher prices. Contrary to previous studies, sustainability practices related to the social and environment dimensions have an indirect impact on willingness to pay higher prices and are mediated by loyalty and satisfaction. The difference in results might be explained by the fact that consumers may be willing to pay higher prices if they view the company's sustainability practices as adding value to their experiences with hospitality products and services (Tarfasa and Brouwer, 2013), thereby increasing their satisfaction. Therefore, if sustainability practices increase satisfaction, hospitality consumers may be more willing to pay higher prices for those sustainable products and services compared to practices that do not have any direct impact on their satisfaction (Parsa et al, 2015). 
Additionally, this study identified significant positive relationships between economic sustainability practices and individuals' attitudes and behaviours; thereby, adding to extant literature on the impacts of economic sustainability practices on hospitality consumers' attitudes and behaviours, which has been growing in recent years (Buckley, 2012, Xu and Gursoy 2015a). Findings in this study indicate that hospitality companies' positive financial results including market share, revenue growth and effective cost control can have positive impacts on consumers' satisfaction, loyalty and willingness to pay higher prices. Consumers may care about hospitality companies' operating and profitability efficiencies as positive results may enable companies to provide high quality hospitality experiences and services and, hence, increase their brand reputation (Xu and Gursoy, 2015a). Positive financial performance may enable hospitality companies to offer additional differentiated and higher quality hospitality experiences and services. Findings also confirm the existence of significant positive relationships between consumer satisfaction and consumer loyalty as well as a significant positive impact of loyalty on consumers' willingness to pay a premium for sustainable products and services, as indicated in extant literature (e.g. Nunkoo et al, 2013).

\section{Conclusions, Implications and Limitations}

This study investigated the impacts of sustainability practices of companies in a hospitality supply chain on consumers' perceptions and behavioural intentions utilising data collected from European consumers. Interesting conclusions emerge which inform existing knowledge on sustainable hospitality supply chain management. First, while economic sustainability practices have significant positive impacts on satisfaction, loyalty and willingness to pay higher prices, environmental and social sustainability practices have significant direct positive impacts on satisfaction and indirect impacts on loyalty and willingness to pay higher prices. As the impacts of sustainability practices associated with each dimension on consumers' attitudes and behaviours tend to vary, it is critical for hospitality companies to prioritise their sustainability initiatives and actions based on the estimated positive influence of each sustainability practice on consumers' perceptions and intentions. Second, findings suggest that satisfaction is likely to mediate the impact of environmental and social dimension practices on consumer loyalty. Sustainability practices of companies in a hospitality supply chain can directly influence consumer satisfaction, which in turn may result in higher consumer loyalty and significantly greater willingness to pay higher prices. Furthermore, initiation and implementation of sustainability practices can improve the financial performance of all the members in a hospitality supply chain (Hall et al, 2012). Thus, participation of all the companies that are part of a hospitality supply in sustainability practices can have significant positive impacts on companies' success. Long-term focus on collaboration and cooperation and sharing critical market information may help all companies in the supply chain to maximise their profits.

Members of a hospitality supply chain should develop and improve social and environmental sustainability practices by investing additional resources in those areas that will improve their financial performance. Such strategies may include actions to operating efficiencies by decreasing costs or improving productivity since improvements in operating efficiencies will result in improved financial performance. Improved financial performance can further enable companies to offer higher quality hospitality experiences that may result in higher satisfaction, loyalty and willingness to pay higher prices (Singal, 2014; Sun and Kim, 2013; Xu and Gursoy, 2015a). Additionally, companies in a supply chain can develop human resource policies and practices to recruit and retain locals as employees, who may help hospitality companies to provide outstanding hospitality experiences with a local flavour. They may also need to provide ongoing training to employees in order to enhance the quality of hospitality experiences provided to consumers and improve the service delivery process, 
which can provide invaluable value-added benefits to consumer (Kim et al, 2015). This process may ultimately result in increased loyalty and greater willingness to pay higher prices (Tarfasa and Brouwer, 2013). Furthermore, developing and implementing initiatives and practices to make local businesses part of the supply chain may also improve consumers' perceptions and behavioural intentions. For example, local businesses such as locally-owned farms, local equipment and furniture manufacturers, local craft producers, local educational institutions and so on may be integrated into the supply chain as the upstream members of the hospitality supply chain. These local upstream members can deliver products and services to midstream enterprises such as hotels (Xu and Gursoy 2015a). For example, hotels and restaurants can directly purchase fresh, flavourful ingredients for their menu items directly from locally-owned farms, furniture from local equipment and furniture manufacturers and local artworks and crafts directly from local artists. Local educational institutions can provide training and educational opportunities to employees so that they advance their careers. Integration of local businesses into the hospitality supply chain as upstream members may have significant impacts on how consumers view those companies in the hospitality supply chain. Integration of local elements such as local customs and culture into the service delivery process and design of facilities is also vital (Kasim et al, 2018). Such integration can help businesses in the supply chain to provide authentic and unique experiences to their end users. Furthermore, such integration might also be viewed as valueadded benefits to consumers and, thus, improve their satisfaction and reinforce loyalty and willingness to pay higher prices for that experience (Perez et al, 2012; Scarpa et al, 2008).

Though this study makes meaningful theoretical and practical contributions to the knowledge in the hospitality field, it is not without limitations. The study focuses only on the sustainability practices of companies that are part of a hospitality supply chain. It does not control for the possible differences that may exists in consumers' perceptions towards sustainability practices of upstream and midstream companies in the supply chain. While some businesses in the hospitality supply chain have close encounters with consumers, others may not have any contacts with consumers. Consumers may not even be aware of the existence of some of the companies that are part of the hospitality supply chain. The level of interaction and consumers' level of knowledge can have significant impacts on consumer perceptions and behavioural intentions. Furthermore, consumers' socio-demographic characteristics and their personality traits may moderate how they view these impacts. Future research should investigate the potential moderating effects of consumers' socio-demographic characteristics and the level of interactions between the relationship of hospitality businesses' sustainability practices and consumer attitudes and behaviours. Though sustainability in the hospitality supply chain management may yield remarkable results for hospitality companies, the costs of developing and implementing those sustainability practices cannot be ignored. This paper primarily focuses on the positive outcomes of sustainability practices, yet does not examine the cost, the type and the number of sustainability practices that need to be developed by each member of a sustainable hospitality supply chain. Future studies should examine the cost structure and the possible benefits of each sustainability practice that each member of a hospitality supply chain may need to develop.

\section{References}

Ashby, A., Leat, M. \& Smith, M.H. (2012). Making connections: a review of supply chain management and sustainability literature. Supply Chain Management: An International Journal, 17 (5), 497-516.

Bechwati, N.N. (2011). Willingness to pay for professional services. Journal of Product 
Brand Management, 20 (1), 75-83.

Berezan, O., Raab, C., Yoo, M. \& Love, C. (2013). Sustainable hotel practices and nationality: the impact on guest satisfaction and guest intention to return. International Journal of Hospitality Management, 34, 227-233.

Brown, G. (2007). Corporate social responsibility: brings limited progress on workplace safety in global supply chain. Occupational Hazards, 69 (8), 16-20.

Buckley, R. (2012). Sustainable tourism: research and reality. Annals of Tourism Research, $39(2), 528-546$.

Campbell, J., DiPietro, R.B. \& Remar, D. (2014). Local foods in a university setting: price consciousness, product involvement, price/quality inference and consumer's willingness-topay. International Journal of Hospitality Management, 42, 39-49.

Cantallops A. S. \& Salvi F. (2014). New consumer behaviour: a review of research on eWOM and hotels. International Journal of Hospitality Management, 36, 41-51

Chaudhuri, A. \& Holbrook, M. (2001). The chain of effects from brand trust and brand affect to brand performance: the role of brand loyalty. Journal of Marketing, 65 (2), 81-93.

Chen, R.J. (2015). From sustainability to consumer loyalty: A case of full service hotels' guests. Journal of Retail and Consumer Services, 22, 261-265.

Chen, M.F. \& Tung, P.J. (2014). Developing an extended theory of planned behaviour model to predict consumers' intention to visit green hotels. International Journal of Hospitality Management, 36, 221-230.

Chi, C.G. \& Gursoy, D. (2009). Employee satisfaction, consumer satisfaction, and financial performance: an empirical examination. International Journal of Hospitality Management, $28(2), 245-253$.

Chin, C. H., Chin, C. L., \& Wong, W. P. M. (2018). The Implementation of Green Marketing Tools in Rural Tourism: The Readiness of Tourists?. Journal of Hospitality Marketing \& Management, 27(3), 261-280.

Cicerali, E. E., Kaya Cicerali, L., \& Saldaml, A. (2017). Linking Psycho-Environmental Comfort Factors to Tourist Satisfaction Levels: Application of a Psychology Theory to Tourism Research. Journal of Hospitality Marketing \& Management, 26(7), 717-734.

Cronin, J.J., Smith, J.S., Gleim, M.R., Martinez, J. \& Ramirez, E. (2011). Green marketing strategies: an examination of stakeholders and the opportunities they present. Journal of the Academy of Marketing Science, 39 (1), 158-174.

de Leaniz, P.M.G. \& Rodriguez, I.R.D.B. (2015). Exploring the antecedents of hotel consumer loyalty: a social identity perspective. Journal of Hospitality Marketing and Management, 24 (1), 1-23.

de Grosbois, D. (2012). Corporate Social Responsibility Reporting by the Global Hotel Industry: Commitment, Initiatives and Performance. International Journal of Hospitality 
Management, 31, 896-905.

Fornell, C., Rust, R.T. \& Dekimpe, M.G. (2010). The effect of consumer satisfaction on consumer spending growth. Journal of Marketing Research, 47 (1), 28-35.

Gao, Y. \& Mattila, A.S. (2014). Improving consumer satisfaction in green hotels: the roles of perceived warmth, perceived competence and CSR motive. International Journal of Hospitality Management, 42, 20-31.

Graci, S. \& Kuehnel, J. (2011). How to increase your bottom line by going green. Green Hotels \& Responsible Tourism Initiative. Retrieved from:

http:/green.hotelscombined.com/Pages/MainGreen/Downloads/green-hotel-whitepaper.pdf

Guide Jr., V.D.R., Jayaraman, V. \& Linton, J. (2003). Building contingency planning for closed-loop supply chains with product recovery. Journal of Operations Management, 21 (3), 259-279.

Gursoy, D., Chen, S., J, G. \& Chi, C. (2014). Theoretical examination of destination loyalty formation. International Journal of Contemporary Hospitality Management, 26 (5), 809-827.

Guo, X., Ling, L., Yang, C., Li, Z. \& Liang, L. (2013). Optimal pricing strategy based on market segmentation for service products using online reservation systems: An application to hotel rooms. International Journal of Hospitality Management, 35, 274-281.

Hair JF, Ringle C.M. \& Sarstedt M. (2011) PLS-SEM: indeed a silver bullet. Journal of Marketing Theory and Practice, 19(2):139-151.

Hall. J., Matos, S. \& Silvestre, B. (2012) Understanding why firms should invest in sustainable supply chains: a complexity approach. International Journal of Production Research, 50(5), 1332-1348.

Han, H., Hsu, L.J., Lee, J.S. \& Sheu, C. (2011). Are lodging consumers ready to go green? An examination of attitudes, demographics, and eco-friendly intentions. International Journal of Hospitality Management, 30, 345-355.

Holmes, T.J. \& Yan, R. (2012). Predicting consumers' preferences for and likely buying of local and organic produce: results of a choice experiment. Journal of Food Production Marketing, 18 (5), 369-384.

Jang, Y.J., Kim,W.G. \& Lee, H.Y. (2015). Coffee shop consumers' emotional attachment and loyalty to green stores: the moderating role of green consciousness. International Journal of Hospitality Management, 44, 146-156.

Jensen, M. \& Drozdenko, R. (2008). The changing price of brand loyalty under perceived time pressure. Journal of Product Brand Management, 17 (2), 115-120.

Jung, H.S. \& Yoon, H.H., (2013). Do employees' satisfied consumers respond with a satisfactory relationship? The effects of employees' satisfaction on consumers' satisfaction and loyalty in a family restaurant. International Journal of Hospitality Management, 34, 1-8. 
Kang, K.H., Stein, L., Heo, C.Y. \& Lee, S. (2012). Consumers' willingness to pay for green initiatives of the hotel industry. International Journal of Hospitality Management, 31, 564 572.

Kasim, A., Ekinci, Y., Altinay, L., \& Hussain, K. (2018). Impact of market orientation, organizational learning and market conditions on small and medium-size hospitality enterprises. Journal of Hospitality Marketing \& Management, 27(7), 885-875.

Kassinis, G.I. \& Soteriou, A.C. (2003). Greening the service profit chain: the impact of environmental management practices. Production Operations Management, 12 (3), 386-403.

Kim, H., Cha, J., Singh, A.J. \& Knutson, B. (2013). A longitudinal investigation to test the validity of the American consumer satisfaction model in the U.S. hotel industry. International Journal of Hospitality Management, 35, 193-202.

Kim, M., Knutson, B.J. \& Han, J. (2015). Understanding employee delight and voice from the internal marketing perspective. Journal of Hospitality Marketing and Management, 24 (3), 260-286.

Kotler, P. \& Keller, K. (2006). Marketing Management. Upper Saddle River: Prentice Hall.

Lee C, Segal R, Kimberlin C, Smith WT \& Weiler RM. (2013). Reliability and validity for the measurement of moral disengagement in pharmacists. Research Society of Administration in Pharmacy, 10(2):297-312.

Lee, C., Song, H., Lee, H., Lee, S. \& Bernhard, B.J. (2013). The impact of CSR on casino employees' organizational trust, job satisfaction, and consumer orientation: an empirical examination of responsible gambling strategies. International Journal of Hospitality Management, 33, 406-415.

Lee, J.S., Hsu(Jane), L.-T., Han, H. \& Kim, Y. (2010). Understanding how consumers view green hotels: how a hotel's green image can influence behavioural intentions. Journal of Sustainable Tourism, 18 (7), 901-914.

Lee, S. \& Heo, C.Y. (2009). Corporate social responsibility and consumer satisfaction among US publicly traded hotels and restaurants. International Journal of Hospitality Management, 28, 635-637.

Lo, A., King, B., \& Mackenzie, M. (2017). Restaurant Customers' Attitude toward Sustainability and Nutritional Menu Labels. Journal of Hospitality Marketing \& Management, 26(8), 846-867.

Lo, A., Wu, C. \& Tsai, H. (2015). The impact of service quality on positive consumption emotions in resort and hotel spa experiences. Journal of Hospitality Marketing and Management, 24 (2), 155-179.

Loureiro, S.M.C. \& Kastenholz, E. (2011). Corporate reputation, satisfaction, delight, and loyalty towards rural lodging units in Portugal. International Journal of Hospitality Management, 30, 575-583.

Lu, W. \& Stepchenkova, S. (2011). Ecotourism experiences reported online: Classification of 
satisfaction attributes. Tourism Management, 33(3), 702-712

Mandhachitara, R. \& Poolthong, Y. (2011). A model of consumer loyalty and corporate social responsibility. Journal of Service Marketing. 25 (2), 122-133.

Martinez, P. \& del Bosque, I.R.D. (2013). CSR and consumer loyalty: the roles of trust, consumer identification with the company and satisfaction. International Journal of Hospitality Management, 35, 89-99.

McDougall, G.H.G. \& Levesque T. (2000). Consumer satisfaction with services: Putting perceived value into equation, Journal of Service Marketing, 14(5), 392-410.

Miles, R.E. \& Snow C.C. (2007). Organization theory and supply chain management: An evolving research perspective. Journal of Operations Management, 25 (2007) 459463

Molina-Azorin, J.F., Claver-Cortes, E., Lopez-Gamero, M.D. \& Tari, J.T., (2009). Green management and financial performance: a literature review. Management Decisions, 47(7), $1080-1110$.

Namkung, Y. \& Jang, S.S. (2017). Are Consumers Willing to Pay more for Green Practices at Restaurants? Journal of Hospitality Tourism Research, 41(3), 329 - 356

Nunkoo, R., Gursoy, D. \& Ramkissoon, H. (2013b). Developments in hospitality marketing and management: social network analysis and research themes. Journal of Hospitality Marketing and Management, 22 (4), 269-288.

Onozaka, Y. \& Mcfadden, D.T. (2011). Does local labeling complement or compete with other sustainable labels? A conjoint analysis of direct and joint values for fresh produce claim. American Journal of Agricultural Economics, 93 (3), 689-702.

Parsa, H.G., Lord, K.R., Putrevu, S. \& Kreeger, J. (2015). Corporate social and environmental responsibility in services: will consumers pay for it? Journal of Retail and Consumer Services, 22, 250-260.

Pena, A.I.P., Jamilena, D.M.F. \& Molina, M.A.R. (2013). Antecedents of loyalty toward rural hospitality enterprises: the moderating effect of the consumer's previous experience. International Journal of Hospitality Management, 34, 127-137.

Perez, A., Garcia de los Salmones, M.M. \& Rodriguez del Bosque, I. (2012). The effect of corporate associations on consumer behaviour. European Journal of Marketing, 47 (1), 218238.

Rather, R. A. (2018). Investigating the impact of customer brand identification on hospitality brand loyalty: A social identity perspective. Journal of Hospitality Marketing \& Management, 27(5), 487-513.

Rosseel Y. (2012), lavaan: An R Package for Structural Equation Modeling. Journal of Statistical Software, 48(2), 1-36. 
Sanchez-Fernandez, R. \& Iniesta-Bonillo, M.A. (2009). Efficiency and quality as economic dimensions of perceived value: conceptualization, measurement, and effect on satisfaction. Journal of Retailing and Consumer Services, 16, 425-433.

Scarpa, R., Mara, T. \& Kenneth, T. (2008). Utility in willingness to pay space: a tool to address confounding random scale effects in destination choice to the Alps. American Journal of Agricultural Economics, 90 (4), 994-1010.

Shi, Y., Prentice, C. \& He, W. (2014). Linking service quality, consumer satisfaction and loyalty in casinos, does membership matter? International Journal of Hospitality Management, 40, 81-91.

Shin, Y. H., Im, J., Jung, S. E., \& Severt, K. (2017). Consumers' willingness to patronize locally sourced restaurants: the impact of environmental concern, environmental knowledge, and ecological behavior. Journal of Hospitality Marketing \& Management, 26(6), 644-658.

Singal, M. (2014). The link between firm financial performance and investment in sustainability initiatives. Cornell Hospitality Quarterly, 55 (1), 19-30.

Sipe, L. J., \& Testa, M. R. (2018). From satisfied to memorable: An empirical study of service and experience dimensions on guest outcomes in the hospitality industry. Journal of Hospitality Marketing \& Management, 27(2), 178-195.

Slevitch, L., Mathe, K., Karpova, E. \& Scott-Halsell, S. (2013). "Green" attributes and consumer satisfaction, International Journal of Contemporary Hospitality Management, $25(6), 802-822$

Sun, K. \& Kim, A. (2013). Does consumer satisfaction increase firm performance? An application of American Consumer Satisfaction Index (ACSI) original research article. International Journal of Hospitality Management, 35, 68-77.

Tabachnick, B.G. \& Fidell, L.S. (2007), Using Multivariate Statistics. New York: Allyn and Bacon.

Tarfasa, S. \& Brouwer, R. (2013). Estimation of the public benefits of urban water supply improvements in Ethiopia: a choice experiment. Applied Economics, 45 (9), 1099-1108.

Teng, C.C., Horng, J.S., Hu, M.L., Chien, L.H. \& Shen, Y.C. (2012). Developing energy conservation and carbon reduction indicators for the hotel industry in Taiwan. International Journal of Hospitality Management, 31, 199-208.

Thompson, A. (2007). Survey: Europeans More 'Green' than Americans. In Live Science. Retrieved September 5, 2018, from http://www.livescience.com/4695-survey-europeansgreen-americans.html.

Wang, Y.F., Chen, S.P., Lee, Y.C. \& Tsai, C.T. (2013). Developing green management standards for restaurants: an application of green supply chain management. International Journal of Hospitality Management, 34, 263-273.

Wheaton, B., Muthen, B., Alwin, D., F. \& Summers, G. (1977). Assessing Reliability and 
Stability in Panel Models, Sociological Methodology, 8 (1), 84-136.

Wu, H. C., \& Cheng, C. C. (2018). What Drives Experiential Loyalty Toward Smart Restaurants? The Case Study of KFC in Beijing. Journal of Hospitality Marketing \& Management, 27(2), 151-177.

Xu, X. \& Gursoy, D. (2015a). A conceptual framework of sustainable hospitality supply chain management. Journal of Hospitality Marketing and Management, 24, 229-259.

Xu, X., \& Gursoy, D. (2015b). Influence of sustainable hospitality supply chain management on customers' attitudes and behaviors. International Journal of Hospitality Management, 49, 105-116.

Yu, Y., Li, X. \&Jai, T. (2017). The impact of green experience on consumer satisfaction: evidence from TripAdvisor, International Journal of Contemporary Hospitality Management, 29(5), 1340-1361

Zhang, X., Song, H. \& Huang, G.Q. (2009). Tourism supply chain management: a new research agenda. Tourism Management, 30 (3), 345-358. 